\title{
Cada coisa em seu lugar. Ensaio de interpretação do discurso de um museu de história
}

\section{José Bittencourt}

Museu Histórico Nacional

Bazares unidos e coesos

Examinando alguns museus, particularmente os de história, ao longo da primeira metade do século XX, tenho a impressão de estar diante de uma casa das maravilhas. Melhor - talvez mais adequado falar em um bazar, um imenso bazar onde as antigüidades da Pátria eram reunidas e mostradas. Um bazar de Maravilhas, constituído pela "miscelânea histórica" acumulada pelas atividades de recolhimento da instituição desde seus primórdios" ${ }^{1}$.

Experimente o observador contemporâneo examinar fotografias de uma exposição daquela época. A museografia (um conceito atual, cuja aplicação a um contexto de setenta anos atrás é complicadal é de difícil percepção, e a expografia inexiste. Os objetos, por vezes, podem parecer velharias recolhidas ao acaso; cuidados mínimos de conservação, só se nosso observador conseguir imaginar, nas fotos, um ambiente sem poeira ou agentes agressores - o que, certamente, exige mesmo muita imaginação.

E os museus, todos, passavam por dificuldades: falta de investimentos, falta de pessoal capacitado, ambigüidade governamental: os governantes amavam as casas, mas thes davam pouco apoio.

De fato, as fotos parecem mostrar bazares.

Mas é preciso fazer uma advertência ao observador neófito no tema: as fotos podem enganar. Não que as observações feitas acima sejam incorretas. $\bigcirc$ que é difícil perceber é a unidade de princípios que ordenava o interior dessas instituições. E essa unidade fundava-se nos princípios conceituais unívocos que orientavam a formação de acervos e a atuação técnico-profissional dos servidores.

Desde o início, uma política de aquisição de acervos (muito embora nunca tenha recebido tal nome) foi estabelecida com base nas diretrizes
1.A expressão é de Daryle Williams, que a utiliza em um artigo sobre o Museu Histórico Nacional publicado em 1997.Williamns, Daryle. "Sobre patronos, heróis e visitantes: $\mathrm{O} \mathrm{Mu}$ seu Histórico Nacional, 1930-1960." Anais do Museu Histórico Nacional, v. 29, p. 141-183, 1997. 
conceituais adotadas pela instituição, estas baseadas nas proposições historiográficas formuladas, ao longo dos setenta anos anteriores, pelo Instituto Histórico e Geográfico Brasileiro. Isto resultava numa perfeita unidade interna de princípios, e o "bazar das maravilhas" se transmuta, quando examinado com base nas tais diretrizes, numa coleção de objetos de admirável consistência. E essa consistência revela os princípios conceituais - e estes, até determinado período, podiam ser notados até mesmo na espécie de mobiliário adotado pelas instituições.

É o que pretendo examinar, daqui por diante: alguns poucos aspectos de uma instituição em particular, em uma época específica: o Museu Histórico Nacional, no período entre 1922 e 1950. O período foi delimitado com base no fato de que o surgimento do Museu Histórico marca um novo momento no movimento brasileiro de museus, servindo de modelo para diversas outras que se seguiriam. Além disso, a "unidade de princípios" de que falamos tornou-se de tal maneira forte que, ainda hoje, suas marcas teimam em se deixar ver nas políticas e ações de boa parte das instituições museológicas brasileiras.

- tema é o discurso do museu e seus desdobramentos, conforme materializados nas exposições e nos trabalhos de pesquisa dos conservadores, desenvolvidos tendo os objetos como base e documentação.

Numa primeira etapa, examinarei como se forma o discurso de uma instituição museológica, ao longo de um período bem delimitado. Em seguida, analisarei dois desdobramentos desse discurso, conforme se manifestam nas exposições e nos textos técnicos: as relações do Estado com o povo, no que tange à ordem; e o lugar do povo no interior do Estado, no que tange a seu funcionamento.

A história tornada matéria - uma trilha de indícios

Os museus são o tempo e o espaço tornados matéria, e a matéria é o meio a partir do qual toma forma o particular tipo de discurso histórico que examinarei. Falar da "história tornada matéria" é uma das maneiras possíveis de começar a falar em museus. Mas também é uma forma de introduzir questões conceituais. Para tanto, apresentarei duas formulações, cuja aplicabilidade aparecerá ao longo de todo o ensaio.

A primeira delas, a cultura material, toca diretamente ao tipo de instituição que coloco em tela. Mais adiante, procurarei situá-la de forma a determinar a posição dos museus com relação a tal campo de conhecimento. $O$ segundo aspecto refere-se ao método de trabalho adotado pelos conservadores de museus, no período que examinamos. Tem sido dito que tal método consiste em uma adaptação dos cânones positivistas ao tipo de documento com que lidavam aqueles profissionais, configurando-se como um tipo de pesquisa aplicada. Isto é correto, mas não bastante. $\bigcirc$ trabalho dos conservadores mergulhava na intimidade mais recolhida do documento, buscando nele sinais que situassem o possuidor, o fato histórico e a época - uma espécie de tríade mítica que o objeto materializava. Examinar o objeto significava superar a invisibilidade irreversível do passado.

Carlo Ginzburg é um teórico que, em princípio, não parece muito afeito a museus. Seus objetos situam-se nas lonjuras do século XVII, e na direção 
oposta de onde se constituíram os museus. Sua vasta obra é bastante consistente em abordar a cultura popular, e a trilha que segue para alcançá-la, a essência de seu método, é apresentada no artigo Sinais - raízes de um paradigma indiciário². $\bigcirc$ artigo trata de um possível paradigma indiciário, "amplamente operante, de fato, ainda que não teorizado explicitamente" 3 . Ginzburg parece, ele mesmo, um incansável perseguidor de indícios que, reunidos e interpretados a partir de códigos, delimitam trilhas e indicam pontos de chegada. "As referências de Menocchio às suas leituras nos dão um exemplo claro deste tipo de relação com o texto [...]. Tais referências nos permitem medir a defasagem [...] entre os textos da literatura 'popular' e o modo como eram lidos por camponeses e artesãos"4.

Os material culturalists e os "historiadores sociais" norte-americanos e ingleses são menos conhecidos e populares, mas talvez seja possível a construção de uma "ponte" com a proposta de Ginzburg. Como este último, também perseguem pistas, mas "pistas materiais". "A história 'positivista' costuma, muitas vezes, negligenciar o campo em que transitam essas pessoas, ao colocar 'a vida material [como] unicamente o palco onde se movem os atores da história" "5. Os autores desta afirmativa, Robert Buccaile e Jean-Marc Pesez, especialistas em história da cultura material, parecem pretender colocar seu objeto numa dimensão que abarca a própria história. Situam o objeto geral das pesquisas dessa disciplina como "o homem", situado este na ordem da longa duração e das estruturas. O que importa, pelo menos no âmbito limitado deste artigo, é que,

[...] em anos recentes [...] a interpretação da cultura material tem se tornado uma preocupação acadêmica. Uma razão para isto é o fato de que as coleções museológicas representam a cultura material armazenada desde o passado, enquanto as exposições museológicas são o principal meio através do qual o passado é publicamente apresentado $[\ldots]^{6}$.

Buccaile e Pesez não se referem a museus - talvez estas instituições estejam no campo dos "elementos destacados" que os dois parecem esconjurar, com um temor verdadeiramente religioso. Mas se conseguirmos combinar as duas proposições, podemos pensar que essas instituições são capazes de mostrar, por meio de suas coleções, "o homem, que é o verdadeiro objeto de sua pesquisa". Pois, segundo os anglo-saxãos, cultura material é um "termo [...] usado significando artefatos construídos por seres humanos através de uma combinação entre matérias brutas e tecnologia, e que, para fins práticos, podem ser distinguidos das estruturas fixas por sua mobilidade"7. Pode-se pensar nesta noção como a expressão material das relações humanas. A cultura material plasma-se em três dimensões: uma espacial (a topologia das transformações naturais e seus resultados visíveis), uma cronológica (que se manifesta em termos de processos evolutivos) e uma terceira, social, que produz diferenças no interior de um mesmo conjunto humano, sendo possível observar níveis de cultura material que separam os grupos sociais ${ }^{8}$. Esses níveis manifestam-se tecnicamente (Bucaile e Pesez parecem pretender que o nível materialtecnológico é a "única certeza"); economicamente, mas também simbolicamente. As coleções museológicas parecem abarcar as três dimensões propostas pelos dois teóricos franceses, e lançam a questão da cultura material muito além dos limites paradoxalmente estreitos por eles estabelecidos?.

problema é que, nos objetos descontextualizados ${ }^{10}$, as tais dimensões podem não ser evidentes, e têm de ser procuradas. Elas se situam em sinais por vezes ínfimos, que só se revelam se investigados.
2. GINZBURG, C. Sinais raízes de um paradigma indiciário. In: MITOS, emblemas, sinais: morfologia e história. São Paulo: Cia das Letras, 1990 . p. 143179.

3. Id., p. 143.

4. GINZBURG, C. O queijo e os vermes. São Paulo: Cia das Letras, 1989. p. 29.

5. BUCCAILE, R.; PESEZ, J. -M. Cultura material. In: ROMANO, R. (Org.). Enciclopédia Einaudi. Lisboa: Imp. Nacional : Casa da Moeda, 1989. v. 17, p. 44

6. PEARCE, S. Museum studies in material culture: introduction. In: PEARCE, S. (Ed.). Museum studies in material culture. London:Leicester University Press, 1989.p.1.

7. Id., p. 2.

8. BUCCAILE, R.; PESEZ, J. -M. op. cit. p. 46

9. Id., p. 46

10. No jargão da museologia, este termo costuma ser usado para designar um objeto incorporado às coleções de um museu, quer dizer, retirado de seu contexto de uso. 
11. GINZBURG, C. Sinais - raízes de um paradigma indiciário.In: GINZBURG, C. Mitos, emblemas [...] op. cit., p. 144.

12. Id., p. 150

13. CARVALHO, Nair de M. O Barão da Vitória no Museu Histórico. Anais do Museu Histórico Nacional, v. 3, p. 227, 1942.

14. Id., p. 227.

15. GINZBURG, C. op.cit. In: MITOS, emblemas [...] op. cit., p. 155.

16. BARROSO, G.A heráldica dos vice-reis. Anais do Museu Histórico Nacional, v. 3, p. 5-6, 1942.
[...] É necessário examinar os pormenores mais negligenciáveis, e menos influenciáveis pela escola a que o pintor pertencia: os lóbulos das orelhas, as unhas, as formas dos dedos das mãos e dos pés. Dessa forma, Morelli descobriu, e escrupulosamente catalogou, a forma da orelha própria de Botticelli, a de Cosme Tura e assim por diante: traços presentes nos originais, mas não nas cópias ${ }^{11}$.

Giovanni Morelli, o inventor do método indiciário investigado por Ginzburg, preocupava-se com a autenticação de obras de arte. Também era esta a preocupação dos conservadores do Museu Histórico Nacional. Nos textos que produziam, sob a forma da exposição, ou de monografias publicadas nos Anais do Museu Histórico Nacional, estes profissionais revelavam-se investigadores de indícios, legados pelas grandes figuras e pelos grandes acontecimentos da história pátria, e ocultos nos objetos materiais. No artigo de Ginzburg a que nos referimos, o autor aponta três rastreadores de indícios cujos métodos em muito se aproximam.

Vimos, portanto, delinear-se uma analogia entre os métodos de Morelli, Holmes e Freud [...] Nos três casos, pistas talvez infinitesimais permitem captar uma realidade mais profunda, de outra forma inatingível. Pistas: mais precisamente sintomas (no caso de Freud), indícios (no caso de Sherlock Holmes), signos pictóricos (no caso de Morelli)12.

Já os conservadores do Museu Histórico Nacional também buscavam pistas, e lidando com uma dificuldade adicional: num museu, um objeto, em muitos casos, pode não se distinguir em nada das imensas quantidades de itens do mesmo tipo. Afinal, uma espada é uma espada, visto que ela não fala. Ou fala?

Museu Histórico Nacional possui em suas coleções de relíquias militares um sabre de honra que pertenceu ao general José Joaquim Coelho, barão da Vitória, e foi adquirido a um de seus descendentes. É uma peça que se autentica por $\mathrm{si}^{13}$.

Autentica-se por si só? Afirmação arriscada, além de curiosa. No mesmo texto, logo em seguida: "Verdadeira obra de arte, com copo e guarnições de prata dourada e cinzelada a mão [...]. Lâmina com ramagens damasquinadas, cujo ouro a ferrugem fez quase desaparecer." 14

Claro, existem elementos que só o olhar treinado capta. Os detalhes da espada do barão a individualizam diante das outras espadas (à parte o fato de ser um sabre de honra - uma espécie de condecoração), no universo interminável dos objetos desta categoria. "Apenas observando atentamente e registrando com extrema minúcia todos os sintomas - afirmavam os hipocráticos - é possível elaborar 'histórias' precisas de cada doença; a doença em si é inatingível." 15 Registrar com extrema minúcia era exatamente o que faziam os conservadores, no decorrer de suas investigações, levantando detalhes que podemos, quando desavisados, chegar a tomar como tolices. Recorramos a outro exemplo:

Os escudos em que se pintam, interna ou externamente, os símbolos desta florida linguagem podem ser de metais, cores ou peles, considerados os primeiros e os segundos como "esmaltes". Os metais são dois, as cores cinco e as peles quatro: ouro e prata; azul, vermelho, verde, negro e púrpura; arminho e contra-arminho, veiros e contraveiros. Além dessas, as cores de carnação e as naturais de animais, vegetais e minerais ... Em Portugal, a púrpura é denominada, às vezes, "sanguinho". Há especialistas que nem a púrpura admitem, assegurando que ela provém de um equivoco; os brasões recobertos de prata brunhida ou folheada perderam o brilho ... com a ação do tempo, e adquiriram o tom avermelhado ${ }^{16}$. 
Uma linguagem hermética, aparentemente destinada mais a confundir do que a esclarecer. Mas o artigo, um cuidadoso estudo sobre os brasões dos vice-reis brasileiros, destina-se a fornecer subsídios que explicassem tais símbolos. Uma vez destrinchada a linguagem própria dos objetos, estes...

[...] falariam de sua nobreza, e lembrariam o valor das estirpes em que se radicavam. Diriam ainda da importância que as mais altas e prestigiosas figuras da Corte ... davam ao cargo de legados do rei na minha pátria distante e ainda semibárbara ${ }^{17}$.

estudo dos brasões permite identificar, com certeza, a origem de centenas de outros objetos depositados na Casa do Brasil, testemunhando sua autenticidade. Mas, como dizíamos, colocado diante do olhar do especialista e confrontado com o código que ele domina, o objeto fala. O problema é que, como diz Ginzburg, "[...] trata-se, de fato, de disciplinas eminentemente qualitativas [refere-se à história e à medicina], que têm por objeto casos, situações e documentos individuais, enquanto individuais" 18 . Os casos com que se batem os conservadores também são individuais, radicalmente individuais. Cada objeto é um testemunho único, que o investigador busca decifrar - uma forma científica de alcançar um objetivo maior: a verdade histórica. Esta se cristaliza em milhares de casos individuais devidamente decifrados. Mas os testemunhos, como veremos, não têm efeito sozinhos: devem se juntar em algum momento. É necessário juntar, somar os indícios, de forma que, ao observador, não possa restar a menor sombra de dúvida.

museu - depósito de provas

Nos dias atuais, existem museus de todos os tipos: de arte, de história natural, de história e de ciência e tecnologia, somente para citar os exemplos mais comuns. Dedicam-se a campos específicos do conhecimento humano, que, reduzidos ao espaço museológico, tornam-se visíveis: é possível representar um resumo da história do mundo (a dimensão cronológica), tanto quanto um resumo da distribuição de tal história (a dimensão topológica) ${ }^{19}$.

Mas, se os itens expostos em um museu representam o mundo, não pertencem mais a ele. Retirados de seu contexto, passam a simulacros que exemplificam uma classe ou grupo de itens do mesmo tipo. Neste sentido, segundo Deloche $^{20}, "[\ldots]$ as múmias egípcias não pertencem mais a tempo algum, e as medidas sofisticadas de que são hoje objeto criam somente a ilusão de um exame telescópico do tempo". A múmia é um sinal, um dos incontáveis milhões de indícios que o passado largou, desorganizados, sobre o mundo. Quando situada na exposição de um museu, não mostra nem o passado nem o mundo, mas uma proposta que, dentre outras indicações, situa o passado e organiza o mundo. Se o museu pode ser dado como um tipo de pedagogia, esta traz, embutida, a revelação de uma ordem.

Quando surgiram no século XVII, os antepassados dos museus atuais buscaram substituir a miscelânea das coleções de curiosidades e antigüidades por uma ordem, fundada nas noções de hierarquia e de disciplina que começavam a predominar sobre as sociedades. As exposições são mais um dos instrumentos
17. Id., p. 14.

18. GINZBURG,C.op.cit., p. 156.

19. Sobre este assunto,ver DELOCHE,B.Museologia e instituições museológicas como agentes ativos da mudança: passado, presente e futuro. 2 . ed. Rio de Janeiro: SPHAN/Pró-Memória, 1990. p. 54-58. (Cadernos museológicos, n. 2, dez. 1989). Deloche discute, com base nas formulações de outros autores, a questão do museu como simulação do tempo.

20. Id., p. 55. 
21. Hooper-Greenhill, E. The museum in a disciplinary society. In: PEARCE, S. (Ed.). op. cit., p. 70 .

22. Sobre as origens dos museus de história, ver ALEXANDER, P. Museums in motion. Nashville(EUA): American Association for State and Local History, 1979. cap. 5.

23. HOOPER-GREENHILL, E. The National Portrait Gallery - a case-study in cultural reproduction. Londres: London Institute of Education, 1980. p. 27. Mimeo. da nova visibilidade, desenvolvida com a emergência da sociedade disciplinar, para a qual o controle do espaço físico e do tempo tornou-se, crescentemente, um instrumento de poder.

Juntando pinturas por divisões históricas ou geográficas, em escolas de artistas, apresentase um "livro-imagem" de história da arte. O espaço constitui um verdadeiro esquema de objetos materiais justapostos e diferenciados. O espectador é capaz de ver o panorama da história num golpe de vista. Ver era conhecer. $\bigcirc$ tema tornou-se um tema de contemplação, no qual a exposição de séries de coisas demonstrava uma ordem natural fundamental ${ }^{21}$

Tempo tornado espaço, o espaço tornado instrumento de demonstração de uma ordem natural, e a ordem interpretada por intermédio de indícios. Esta parece ser a receita do museu ideal.

A apoteose do Estado - o museu de história nacional

Os museus de história foram os últimos a surgir, desde a expansão deste tipo de instituição, no período das Luzes. Em França, o Museu dos Monumentos Franceses e o Museu Napoleão eram, basicamente, galerias de arte, mas exibiam também troféus de guerra conquistados pelos exércitos revolucionários. O Museu dos Monumentos Franceses, organizado por Alexandre Lenoir, arqueólogo e literato, recolhia vestígios do passado da França, ainda que tal passado estivesse projetado no início da ldade Média. Anos depois, em 1837, Luís Felipe organizou, no Palácio de Versalhes, uma grande galeria de quadros mostrando grandes batalhas, desde as Cruzadas, passando pelas batalhas de Napoleão e as barricadas de 1830. Conforme passavam os anos, iam sendo acrescentadas representações das novas glórias francesas: a Criméia, a Argélia e as batalhas "moedor de carne" da Grande Guerra. A junção dos quadros de batalhas e dos objetos sobreviventes do passado formaram o embrião do que, pouco mais tarde, se constituiria no atual museu de história 22 .

Os museus de história se tornaram instrumentos de divulgação do Estado nacional que se organizava na Europa. "O novo grupo dominante, e especificamente a nova classe burguesa, precisava estabelecer firmemente seu poder, com referência às suas raízes. $\bigcirc$ passado precisava ser reorganizado e selecionado para conter a nova formação que emergia." ${ }^{23}$ Procuravam demonstrar que as origens da Nação encontravam-se projetadas num passado remoto, ou seja, que a ordem implantada pela burguesia vitoriosa em meados do século XIX transcendia o tempo. Desta forma, a França de Luís Felipe encontrava suas raízes no Sacro Império de Carlos Magno e no reino medieval de Felipe Augusto; na Inglaterra organizava-se, em meados dos oitocentos, a National Portrait Gallery, a partir de uma coleção de "retratos históricos" de reis e governantes.

$\bigcirc$ passado também era representado através de objetos materiais de dois tipos: os objetos históricos, ou seja, que tenham pertencido a vultos históricos; e as curiosidades, estas em geral referentes ao "povo", esta misteriosa instituição foriada pelo romantismo. As duas histórias não se misturavam. Os museus "de história" ficavam geralmente com os retratos e com armas, armaduras, tronos, moedas e coisas afins. $\bigcirc$ "povo" caminharia para museus 
"de cultura" que, pelo menos em alguns casos, se revelariam muito avançados em termos de proposta.

No Brasil, a proposição romântica de descobrir o Estado nacional no passado permaneceu, durante muito tempo, diluída na proposta de classificação do mundo. Por sinal, tal trabalho - criar o passado do Estado nacional - ficaria, durante bastante tempo, a cargo do grande museu brasileiro de história natural: o Museu Imperial e Nacional.

No final do século XIX, após a Proclamação da República, o estado dos museus existentes era considerado insatisfatório. No Rio de Janeiro, os clamores pela instalação de um novo museu eram tímidos, e geralmente não encontravam eco nas autoridades. $\bigcirc$ Arquivo Nacional e a Biblioteca Nacional possuíam coleções de história, formadas por objetos tridimensionais, retratos, moedas e medalhas; o Museu Nacional também possuía "objetos históricos"; pequenos museus de história funcionavam em instituições como o Colégio Militar e a Academia Nacional de Medicina. Entretanto, estes pequenos museus eram pouco mais do que reuniões de objetos, sem nenhuma técnica de exposição ou preocupação com o público 24 .

A idéia de um museu de história nacional só seria concretizada em 1922, por ocasião da grande exposição internacional comemorativa do centenário da Independência. Foi fundado e organizado por um membro da aristocracia nordestina decadente que havia estudado no Rio de Janeiro, Gustavo Dodt Barroso. Nessa época, Barroso, um erudito generalista, já tinha passado por diversas atividades, inclusive no serviço diplomático, e se fixara na carreira de jornalista. Vinha, desde 1911, fazendo propaganda da necessidade da instalação de um museu militar. Anos depois, essa idéia evoluiu para a de um museu de história baseado na noção de "culto da saudade". Em 1920, escrevia ele:

Verifica-se, com tristeza, e a cada passo, que no Brasil quase não há o culto das tradições. Aqui no Rio são às centenas os exemplo desse asserto [...]. As maiores relíquias de nossa tradição andam esparsas e ao abandono [...] O culto da saudade é coisa que não existe entre nós ${ }^{25}$

que Barroso propõe é basicamente um monumento ao Estado nacional, mas um monumento que o celebrasse como uma ordem vitoriosa, subjugando adversários externos e internos, se e quando aparecessem. Nessa construção, o Estado é gerado por um núcleo guerreiro e se reproduz no culto a tal tradição. Assim, como não poderia deixar de ser, o museu de história se encheu de armas. $\bigcirc$ Catálogo Geral do Museu Histórico Nacional, aparecido em 1924, primeiro documento publicado sobre a então novíssima instituição, relaciona 2.496 itens em exposição, dos quais a terça parte, seguramente, eram armas ou objetos com alguma espécie de origem militar. As fotografias que exibe essa publicação mostram algumas salas abarrotadas de armas e de troféus militares ${ }^{26}$.

A organização essencial do museu merece um exame. Suas instalações situavam-se no edifício do antigo Arsenal de Guerra do Rio de Janeiro, "um dos mais antigos e históricos do Rio de Janeiro", segundo a abertura do Catálogo. Em 1924, estendia-se por 21 áreas de exposição, que podiam ser salas, varandas, escadas ou pátios de ligação interna. Diz o texto da época:
24. Uma boa descrição de museu do século XIX encontra-se no volume da Revista do Instituto Histórico e Geográfico Brasileiro para 1843 . Com admirável sinceridade, o doutor Moreira de Azevedo, então secretário da instituição, descreve o "museu" e suas preciosidades. Começa por dizer que não havia, por deficiência das instalações, uma sede fixa; fala de objetos espalhados pelo chão e "expostos em armários fechados". Além disso, não se refere a visitantes, apenas dizendo que certos objetos são de agrado geral.V. INSTITUTO HISTÓRICO E GEOGRÁFICO BRASILEIRO. Objetos do museu- catálogo organizado pelo $1^{\circ}$. secretário Dr. Moreira de Azevedo. RIHGB (Tomo XLIX, 1886). $2 \mathrm{v}$.

25. Barroso, G. apud DUMANS,A.A idéia da criação do Museu Histórico Nacional. Anais do $\mathrm{Mu}$ seu Histórico Nacional, $\mathbf{v}$. 3, p. 388, 1942.

26. Cf. BRASIL. Museu Histórico Nacional. Catálogo geral. Rio de Janeiro:Imp. Nacional, 1924. A capa e a contracapa eram ilustradas com fotografias de objetos militares. 
27. Id., p. 4.

28. Id., p. 17.

segundo [...] estão ocupados pela Seção de Arqueologia e História. $\bigcirc$ visitante que desejar visita-la toda, entrando no Museu, tem à sua direita a Portaria, a Ala dos Candelabros, a Sala dos Ministros e o Gabinete do Chefe da Seção; à sua esquerda, a Sala dos Retratos e das Bandeiras. A sua frente está o passadiço que o leva [...] ao $2^{\circ}$ corpo do edifício, onde se abrem sobre o Pátio das Coroas as Árcadas dos Canhões, das Pedras e dos Coches. No encontro destas duas, a escadaria dos escudos conduzilo-á, à esquerda, às Salas dos Tronos, do Cetro, da Constituinte e dos Capacetes; à direita, as Salas Osório e dos Troféus. No patamar dessas duas, a Escadaria dos Escudos dar-the-á acesso à Galeria das Nações e às Salas da Abolição e do Exílio, e da República ${ }^{27}$

Segundo o texto acima, cada uma das áreas de exposição representava um período histórico, dado que era informado no Catálogo, mas não no próprio recinto. $\bigcirc$ visitante deveria deduzir a cronologia com base na ordem das salas e nos objetos contidos nelas. Por exemplo: a "Ala dos Candelabros" continha quinze objetos, dos quais doze eram itens de uso religioso, recolhidos em igrejas demolidas ou reformadas. Os três restantes eram grandes peças de mobiliário pertencentes ao rei D. João VI. A época é, pois, a época colonial, mas isto o interessado na história pátria teria de adivinhar, pois as etiquetas não continham informação de datação. Em seguida, passava o visitante à "Sala dos Ministros". A coisa então se complicava, pois esta sala continha 311 objetos recolhidos do extinto Museu de Artilharia, um museu pedagógico do Exército cujas coleções se destinavam à instrução de oficiais. Lá dentro se encontravam desde os "Sabres de cavalaria brasileira da época da Independência, vulgarmente chamados rabos de gallo", até a "Clavina francesa do systema Lebel, modelo de 1890". O nome da sala derivava do fato de que nela estavam plantados, na mais alta posição (literalmente: a uns dois metros e tanto do chão) uma série de "[...] retratos dos ministros da Guerra do Brasil, desde a criação do respectivo ministério, em 1808, até o ano do Centenário da Independência, em 1922"28; também estavam expostos retratos de algumas figuras de vulto da história militar brasileira. Estes últimos e os ministros tinham sido desalojados de um outro museu extinto, o Museu Militar, pequena repartição destinada a contar a história do Exército. Esta sala era dita "de todas as épocas", e algumas das etiquetas traziam datas.

A "Sala dos Ministros", bem como a da "Arcada dos Canhões", a "Sala Osório" e a "Sala dos Troféus" eram estritamente militares, abarrotadas de objetos evocativos das guerras externas enfrentadas pelo Estado brasileiro. Mas as outras salas também tinham sua cota de "relíquias militares", em grande quantidade. Mas, ao contrário das salas anteriores, nestas os itens militares distribuíam-se por entre grande quantidade de retratos, objetos de uso pessoal, medalhas e ornamentos, máscaras mortuárias, peças de indumentária, esculturas, mobiliário e bandeiras.

Até agora examinamos apenas o Catálogo, que relaciona dois e meio milhares de objetos - o que não é pouca coisa. Só que as coleções não pararam de aumentar, nos 25 anos seguintes. A classe dominante, ou pelo menos alguns de seus mais importantes representantes, abraçou a causa de um museu de história. As grandes salas passaram, com o correr dos anos, por várias reformas, para abrigar a crescente quantidade de objetos. Mas, aparentemente, o Museu Histórico Nacional contava a história de um país sem povo. 
29. Para uma introdução ao assunto, v. HORTA, M. L. P. O processo de comunicação em museus. 2. ed. Rio de Janeiro: SPHAN/Pró-Memória, 1990.p. 65-90. (Cadernos Museológicos, n. 1, set. 1989).

30. Id., p. 79.

31. Id., p. 81. ser entendidas como formações discursivas, quer dizer, como atos de comunicação lingüística historicamente condicionados.

Esta não é uma afirmação de pequenas conseqüências: segundo a lingüística, toda vez que alguém diz alguma coisa, opera um par conceitual antinômico - a língua e a palavra. Estes dois conceitos referem-se, basicamente, ao que é social e ao que é individual, no que tange à operação social da linguagem. Mas se, por um lado, a palavra é uma relação efetiva que depende da presença de pelo menos um falante, por outro a língua implica relações virtuais: uma língua pode existir sem falantes. $O$ discurso, como ato de comunicação lingüística, ałua pela relação dos dois níveis brevemente descritos acima. Mas podem existir casos em que a palavra, ainda que relação efetiva, atue sem a presença do emissor. Por exemplo, um texto escrito. Nestes casos, a palavra precisará de um suporte, um tipo de plataforma onde fique registrada após sua emissão. Sem maiores delongas, este nos parece ser o caso dos museus: atuam como uma espécie de suporte para um ato discursivo no qual o emissor está apenas virtualmente presente.

As unidades de significado ou signos utilizados pela linguagem museológica são os objetos da cultura material preservados e coletados ao longo de gerações, assim como todos os fenômenos de natureza cultural, biológica ou natural apresentados e demonstrados ao público, para sua instrução, educação e entretenimento. Diríamos, antes de mais nada, para sua compreensão ${ }^{30}$.

A compreensão é a função primeira do discurso museológico, pois os objetos reunidos destinam-se a transportar uma mensagem e agir sobre os visitantes que entram no espaço do museu para observá-los. A mensagem é, segundo Roman Jakobson, uma das funções do discurso: trata-se da ligação comunicativa que se estabelece entre o emissor do discurso e seu destinatário, através da qual o emissor se autocaracteriza e representa uma realidade extralingǘstica, que é o objeto sobre o qual se formula o discurso. No caso do museu, o emissor é virtual e esconde-se atrás de um contexto, que é a ambiência na qual a mensagem é emitida.

Qual a mensagem essencial transportada pelo discurso museológico? Segundo Hooper-Greenhill, a existência de uma ordem natural fundamental que precede as sociedades humanas. Os museus traduzem, em um código específico, este discurso. Objetos os mais diversos conotam significados além de seus estritos.

No contexto dos museus, fenômenos não-comunicativos adquirem imediatamente o status de signos. [...] A substância significativa desses objetos deriva de sua colocação em uma cadeia de idéias, conceitos ou processos, determinados pelos padrões culturais que ditaram sua criação, ou pelos padrões culturais ditados pelos que os utilizaram ${ }^{31}$. 
32. HOOPER-GREENHILL, E. The museum in a disciplinary society. In: PEARCE, S. (Ed.) - op. cit., p. 71 .

33. Sobre o assunto v. ABREU, Regina.A fabricação do imortal:A coleção Miguel Calmon no Museu Histórico Nacional. Rio de Janeiro: Rocco/Livros Lapa, 1997.
Este é exatamente o ponto em que queríamos desembarcar. HooperGreenhill propõe, em seu artigo, que os museus apresentavam uma dada "verdade", por intermédio das antinomias que a formavam la autora se refere ao contexto histórico da Revolução Francesa e do Império) ${ }^{32}$. No caso que estamos estudando, - processo é o mesmo, mas pudemos perceber a presença de uma antinomia maior: a da presença/ausência. As outras oposições são tributárias desta última. Por exemplo: quando se entra no museu de história, vêem-se objetos históricos. Pode ser que existam outros objetos históricos - até porque existem outros museus de história -, mas a existência de objetos históricos denota a existência de objetos não-históricos. Por conseguinte, a existência de objetos históricos e objetos nãohistóricos qualifica o possuidor do objeto, por denotar a existência de vultos históricos que os objetos rememoram. Resta observar as bases em que eram aplicados os conceitos formados a partir de tais oposições.

Em primeiro lugar, o ordenamento temporal. Os objetos eram, em sua maioria, "antigüidades", isto é, eram legitimados pelo tempo. Este dado era frisado pela ordenação rigorosamente cronológica dos espaços de exposição e dos objetos em seu interior. A maior parte das salas referia-se a todas as épocas, mas o visitante entrava no museu obrigatoriamente pelo Brasil-Colônia e saía pela República.

Outro parâmetro era a origem do item: quem o tinha possuído, ou a que evento histórico ele estava ligado. Para estar no museu de história, os objetos sempre deviam denotar pessoas ou eventos cuja qualidade de "históricos" não pudesse ser colocada em dúvida. Neste ponto deparamos com um momento em que os especialistas atuavam como investigadores de indícios por excelência, pois desta maneira determinavam a "historicidade" do objeto em si, ou seja, estabeleciam as relações dele com o vulto ou fato histórico. A função primeira deles seria, pois, legalizar um testemunho do qual se devia, em princípio, desconfiar.

Por fim, a identidade do doador do objeto. Não necessariamente todos os objetos indicam pessoas que pudessem ser imediatamente entendidas como "históricas", em boa parte dos casos devido à falta da chancela do tempo. Isto, no entanto, não os desqualificava. Entravam em jogo as características intrínsecas do objeto (dentre as quais a antigüidade era apenas um dado, mas não o único e nem sequer o mais importante), e a posição social e/ ou política do doador. Com o tempo, este dado tornou-se extremamente importante, e acabou por determinar um realinhamento dos códigos e signos que conformavam o discurso do museu. E isto fica muito claro se observarmos que as salas, antes denominadas "dos Candelabros", "dos Tronos", "do Cetro", etc., passaram, a partir dos anos 30, a receber nomes de "vultos históricos". Uma parte destes era, entretanto, composta por membros da elite dominante, econômica e política. Em princípio, o Museu Histórico thes fazia tal homenagem pelo fato de essas pessoas terem se constituído como grandes benfeitoras da instituição. Era, claramente, um recurso propagandístico que visava a atrair benfeitores, numa época de pouca ajuda governamental. Procurava chamar a atenção da sociedade para uma possibilidade, que envolvia, por sua vez, uma regime de "trocas simbólicas" - os indivíduos podiam juntar a própria memória à memória nacional preservada pelo Museu ${ }^{33}$. Este pacto, entretanto, não era selado com qualquer um.

O Museu, com a exposição pública de objetos e etiquetas, mostrava a seu público visitante uma certa capacidade de perenizar a memória nacional, e uma capacidade lateral de perenizar a memória dos indivíduos. É significativo 
que, apesar do intenso trabalho de pesquisa que a instituição sempre desenvolveu, as etiquetas fossem em geral pequenas, e as informações repassadas ao público normalmente limitadas a quatro campos: discriminação do objeto propriamente dito, autor (nem sempre), época (idem) e procedência (sempre). Os objetos apareciam discriminados da seguinte maneira: "Aspecto interno e externo da egreja de Humaitá. Litographia da Semana Illustrada, tirada das photografias do natural enviadas pelo coronel J. J. de Lima e Silva. Procedência: doação do Sr. Cesar Lopes ao Museu Histórico." 34 É quase como se objetos feitos para uma duração por vezes efêmera (como, por exemplo, o "penacho de official de infantaria, em grande gala, época da Guerra do Paraguay" - o que poderia ser mais efêmero do que um penacho?) se transformassem, nas salas do Museu, em pequenos monumentos à memória, tanto do possuidor quanto do doador.

Ao longo de seus primeiros 15 anos de existência, o Museu Histórico passou por significativo crescimento institucional, com o acervo aumentando em pelo menos três vezes, e com a ocupação de novos espaços de exposição la instituição dividia o conjunto do Arsenal de Guerra com outras repartições públicas). Após 1937, a época de recursos escassos pareceu acabar, visto que o Estado Novo encontrou, para o Museu, um lugar em seu projeto de apropriação da memória nacional. Tanto é que Getúlio Vargas, personagem que, pela lógica positivista da instituição, só poderia entrar nela bem depois de morto, passou, depois da grande reforma de 1945, a dar nome a uma das salas ${ }^{35}$.

\section{discurso da ordem como diálogo}

Em 1937, um visitante da cidade de Araraquara, entusiasmado com a "vida da tradição" que, em seu entender, era representada no Museu, deu o seguinte testemunho:

\footnotetext{
À entrada, um vasto compartimento, eivado de armas, eretas e firmes, revivendo Tuiuty, Guararapes, Serro-Corá, Riachuelo, e tantos outros sítios, aonde o gênio das batalhas sucessivamente reapareceu no celebrado tropel das nossas culminâncias históricas. Adivinha o cruzar e o recruzar imponente dos grandes feitos que cravaram soberbas etapas na caminhada ascensional de nossa nacionalidade. [...] É o grande exército redivivo. Não o abateu a fúria dos eternos Lopes [...] e muito menos o aniquilou a cruciante abalada sobre Canudos, o revoltado. Fragmentos do Brasil-colonia, restos do Brasil-império [...] estendem-se, distintos, na evocativa intérmina da vida vivida, pejada de idéias contrastantes, amarrados às múltiplas necessidades, mas que obedeciam, no fundo, a uma só diretriz, o futuro da Nação ${ }^{36}$.
}

texto acima está inserido em um livro chamado Relíquias da Pátria Brasileira, reunião de pequenos textos publicado por Pedro Ornellas, secretário de gabinete do Museu Histórico desde a fundação até o final dos anos quarenta. Parece que o autor, senhor Lacorte, jornalista por profissão, percebeu claramente o que o Museu Histórico pretendia dizer. Vejamos algumas daquelas que parecem ser suas idéias centrais: a do gênio das batalhas, aparecendo sempre que necessário impor a ordem; a da caminhada ascensional de nossa nacionalidade, evocando a noção de um destino progressivo e portanto cronológico para o conjunto ordenado; as idéias contrastantes; as múltiplas necessidades: estas últimas são figuras particularmente representativas do diálogo que aparentemente se
34. BRASIL. Museu Histórico Nacional - Catálogo [...] op. cit., p. 135, n. 28. É provável que o Catálogo reproduzisse o texto da etiqueta.

35. Para uma descrição do Museu Histórico Nacional no período de 1945 até meados da década de 50 , verWINZ,A.P.História da Casa do Trem. Rio de Janeiro: Museu Histórico Nacional, 1962. cap. XIII.

36. LACORTE,V. Escola de civismo. In: ORNELLAS, P. da V. Relíquias da pátria brasileira. Rio de Janeiro: [s.n.], 1944. p. 23. 
37. GINZBURG, C. Sinais [...] In: op. cit., p. 158. Grifos do autor.

38. ORNELLAS, P. da V. Museu Histórico. In: ORNELLAS, P.da V.op.cit., p. 27. estabeleceu entre emissores e receptor do discurso. Do lado dos emissores, a enunciação da mensagem parece depender de uma interseção entre aspectos contraditórios. A antinomia fragmentação/reunião talvez seja uma das mais recorrentes no desenrolar da exposição. Estaria sempre presente na história da formação e na existência da nacionalidade; no Museu seria representada pelos objetos singulares (ou conjuntos deles), de um lado, e de outro pela própria idéia de nacionalidade como conjunto.

Carlo Ginzburg apresenta, dentre as disciplinas indiciárias que investiga, a crítica textual, aludindo ao fato de que o texto é uma entidade não confiável e pode ser falsificado com a introdução de dados sensíveis. Apelando a Galileu Galilei, diz ele:

[...] não se pode entender se antes não se aprende a entender a língua, conhecer os caracteres nos quais está escrito. [...] Para o filósofo natural, como para o filólogo, o texto é uma entidade profunda invisível, a ser reconstruída para além dos dados sensíveis $[\ldots]^{37}$.

Sugere que a crítica textual demanda um cuidadoso aprendizado da língua em que o texto está escrito, como uma das formas de superar tais armadilhas. Desta maneira, o investigador ultrapassa o dado sensível, reconstruindo seu objeto de uma forma confiável.

É o que fazem os indivíduos que elaboram a exposição museológica: eles procuram tornar confiável o texto que constroem, e trata-se de um texto particularmente complexo, pois envolve uma relação entre fatos lingüísticos e extralingüísticos. A pedagogia praticada pelo Museu baseia-se em um processo comunicativo no qual os visitantes são colocados diante de um texto no qual irão introduzir dados sensíveis, que são suas próprias emoções. É preciso, assim, que o texto não deixe dúvidas, e que todos quantos entrem nas salas tenham a certeza de que ali está a história, comprovada por intermédio de seus testemunhos. Desta maneira, o Museu ensina seus visitantes a ler e entender seu texto, composto por objetos materiais. Aquele deve, por conseguinte, ser suficientemente claro para que o ato comunicativo seja estabelecido e a mensagem transmitida. E, principalmente, para que o observador possa distorcê-lo sem modificar a mensagem essencial, ainda que o emissor não esteja presente para regular a relação comunicativa.

Voltemos agora ao ponto anterior: o lugar de cada um no conjunto da ordem está representado no discurso do Museu. Não é preciso ler etiquetas para entender que, se a natureza aparentemente cria certas igualdades, estas são apenas aparentes. Acima e dentro da natureza está a ordem; dentro da ordem, a hierarquia.

[...] as grandes vitrines que adunam e guardam cristais e louças, assim como numerosas porcelanas, pratos, xícaras, baixelas, travessas diversas dos serviços de mesa, tudo de finíssima qualidade, que pertenceram ao barão de Massambará, ao visconde e barão do Rio Branco, a D. Pedro I e D. Pedro II, tendo gravadas as efígies dos respectivos titulares, encimadas de brasões de armas heráldicas $[\ldots]^{38}$.

Quer dizer, comer, todo mundo come, e em pratos - quase todo mundo, pelo menos. Mas comer em pratos de "finíssima qualidade" é atributo apenas de alguns. Esta mensagem, mais do que uma etiqueta contendo um texto escrito, se constrói através de um jogo sutil de inclusão/exclusão, tornado possível na medida 
em que o receptor conhece os objetos como significantes de seu cotidiano e se remete o tempo todo a eles. Pensada estritamente como conceitos, parte dos itens expostos - armas, pratos, roupas -

[...] não pode ser explicada cabalmente como obra de arte, ou vice-versa [uma obra de arte ser explicada como objeto utilitário]. Por mais complicado que seja seu mecanismo, o utensílio será sempre intrinsecamente simples, ao passo que a obra de arte é um complexo de vários estados e níveis de intenções intrincadas, por muito simples que possa parecer será sempre uma coisa intrinsecamente complicada $[\ldots]^{39}$.

Mas podemos dizer que os objetos musealizados são diferentes. São mais do que conceitos: muitos podem também ser explicados como obras de arte. Seu mecanismo é, pois, muito sofisticado: além de ter um grau de funcionalidade igual ao dos outros objetos da mesma classe, também funciona para referir o possuidor. $\bigcirc$ visitante observa um prato, talher ou arma que se distinguem dos demais. Seus possuidores adquirem, no momento em que se estabelece tal relação, as qualidades especiais destacadas pela exposição.

Aqui se descortina a sutileza da pedagogia do museu. $\bigcirc$ visitante, de fato, não conhece o século XIX, o período colonial ou qualquer outra das épocas que o museu the expõe diante dos olhos. Ele nunca viveu nelas. Os referentes que possui são aqueles da memória coletiva e da história, ambos altamente inconfiáveis, embora ele não saiba disto. Além destes, possui seus próprios referentes: sua vida e os produtos materiais que a tornam possível. Quando começa a comparar, entra na ordem e situa-se na hierarquia. Ou, como disse o senhor Lacorte, quase sessenta anos atrás...

$\bigcirc$ quadro, a espada, o cinturão, o livro, a moeda que porventura ali se encontrem narram os fatos dentro da realidade intuitiva e assumem o poder da convicção, apto a acompanhar o moço estudioso para todo o sempre ${ }^{40}$.

Exclusão/inclusão - um lugar para cada coisa, cada coisa em seu lugar

Nesta vida tem uma moda/De que é bom alembrar,

Tem lugar para cada coisa/Cada coisa tem lugar.

(Dito popular do sul de Minas Gerais, citado por Mário de Andrade).

$\bigcirc$ discurso museológico que analisamos deixa, em alguns momentos, forte impressão de que seus formuladores concebiam a Nação brasileira como uma formação histórica sem povo, apenas com uma elite política, econômica e intelectual. Já podemos agora afirmar que esta idéia é falsa, e nos arriscar a encontrar o povo no museu.

Essa questão foi discutida conceitualmente pelo diretor do Museu Histórico Nacional. Em artigo publicado no terceiro volume dos Anais, diz ele:

Entende-se por ergologia a parte da vida popular que envolve valores úteis ou artes de utilidade: cozinha, ofícios manuais, profissões rústicas, etc. Assim encontramos nesse capítulo folclórico brasileiro uma riqueza formidável, desde os alimentos [...] até as obras dos fazedores de balaios, dos oleiros, dos santeiros, [...] de cercas e de embarcações $[\ldots]^{41}$.

39. George Kubler apud DE SETA, C. Objeto. In: ROMANO, R. (Dir.). Enciclopédia Einaudi [...] op. cit., p. 96.v. 3.

40. LACORTE,V.op.cit. In: ORNELLAS, P.daV.op.cit., p. 25.

41. BARROSO, G. Museu ergológico brasileiro. Anais do Museu Histórico Nacional, v. 3, p. 433 , 1942. 
42. Id., p. 434.

43. HOBSBAWN, E. $A$ era do capital. 3. ed. Rio de Janeiro: Paz e Terra, 1982. p. 104. O autor discute o papel da cultura popular, conforme vista pela classe dominante, nos movimentos nacionalistas europeus do século XIX.
Barroso dá-se conta da infinidade de indícios gerados pela dinâmica daquilo que ele chama "vida popular". Admite que tais indícios devem ser preservados em museus específicos, "utilíssimos e interessantíssimos", conforme adjetivou.

Em geral, os estudos folclóricos [...] se limitam às manifestações da vida espiritual pura. Um estudioso argentino fez a propósito, esta observação: "Uma das raízes que dão vida ao estudo do folclore é a nostalgia com que as classes superiores volvem o olhar para a vida rústica e, inclusive, para os povos situados à margem da civilização [...] Contudo, essa nostalgia, a qual muito deve o folclore e também a etnografia, fez com que se desenvolvesse, de modo sumamente unilateral, o estudo das tradiç̃̃es populares. [...] como a arte popular se resume por excelência no triângulo MUUSICA-DANÇAPOESIA, a maioria, quando não a totalidade virtual das investigações folclóricas é primordialmente levada a cabo nesses três setores da cultura, aos quais se devem acrescentar o da narrativa em prosa, o dos provérbios, o das adivinhações e o das superstições. O que, finalmente, se denomina vida espiritual ou cultura animológica"42.

Desde o início do século XIX, o romantismo buscava, esforçadamente, um Volkergeist que caracteriza as emergentes nações européias. Tal "espírito do povo" (talvez a "cultura animológica" do ensaísta não-identificado citado por Barroso) deveria ser buscado no passado, ou nos estudos folclóricos: era um dos elementos essenciais da nacionalidade. Quando o "estudioso argentino" refere-se à "nostalgia das classes superiores [pela] vida rústica", cria um laço de identificação entre a "alta cultura" e o "povo comum", visto que seria preciso, no mínimo, entender o que a "ratatuia" dizia ou fazia.

\footnotetext{
$\bigcirc$ critério "histórico" de nacionalidade implicava portanto a importância decisiva das instituições e da cultura das classes dominantes ou elites de educação elevada, supondoas identificadas, ou pelo menos não muito obviamente incompatíveis com o povo comum. [...] $\bigcirc$ primeiro estágio desse "renascimento nacional" era encontrar, recuperar e sentir orgulho desta herança de folclore ${ }^{43}$.
}

As práticas identificadas e catalogadas pelo proposto museu ergológico funcionariam como uma espécie de "alma da nacionalidade", porque o intelecto estava situado nas classes superiores e, por conseguinte, no Estado que elas dominavam. Deparamo-nos aqui com um outro par antinômico: alma/ intelecto. Esta nova exclusão precisa ser melhor explicada. Nem Barroso nem o teórico escondido do qual ele lança mão chegam a negar a integração, ao conjunto da nacionalidade, da "tradição popular". Barroso tampouco nega a importância de seus indícios. Entretanto, o museu de história não é o lugar nem para a cultura popular nem para seus testemunhos, que deveriam ser instalados em repartições específicas, pois constituíam um campo de estudos particular, ocupado com fenômenos fora dos limites do intelecto e, por conseguinte, da história.

$\bigcirc$ que não significa que partes desse amplo e misterioso campo não possam ocupar a atenção dos investigadores de indícios dos museus de história: as partes que se cruzem com o objeto desses museus, "os museus do Estado nacional no tempo", um pouco parodiando o conceito de Braudel. Examinarei duas dessas possibilidades de cruzamento: as relações do Estado com o povo, no que tange à ordem; e a presença do povo no interior do Estado, no que tange a seu funcionamento.

primeiro aspecto é mais simples. Em 1947, a conservadora Fortunée Levy, uma das mais operosas investigadoras de indícios do Museu Histórico 
Nacional publicou, nos Anais, um longo artigo intitulado "Crentes e bandidos". Este tinha como motivação o estudo de certos objetos remanescentes de algumas revoltas camponesas acontecidas no Brasil, entre o final do século XIX e o início do XX. A senhora Levy usa, em seu trabalho, método irrepreensível, inteiramente dentro dos postulados que orientavam os conservadores. Abre o ensaio com uma digressão teórica, de extração sociológica, onde procura explicar as motivações dos fanáticos que constituíam a massa de tais revoltas, a quem ela denomina crentes. Deixemo-la falar:

Os pequenos, os pobres, os humildes que formam a [...] legião de agregados amparados apenas pelo [...] chefão político local têm a necessidade inconsciente [...] de uma proteção mais subjetiva.

São essas populações mais tendentes ao desenvolvimento do fanatismo religioso. No sertão, o profeta encontra meio propício ao proselitismo. $\bigcirc$ sertanejo está apto a aceitálo. Convencê-lo não é difícil.

Desde criança, rodeado de curandeiros, ouve casos milagrosos; crê em feitiçaria e bruxedos; usa bentinhos, amuletos, patuás [...] cultiva uma religião indefinida e vária, associando lendas e superstições, de mistura com catolicismo e fetichismo, e se fortalece no fatalismo $[\ldots]^{44}$.

A análise da senhora Levy prossegue nesse estilo. Ela parece encontrar no camponês uma espécie de predisposição à religiosidade rústica lou seja, incultal, à superstição e ao fatalismo. Ela procura, enfim, qualidades "animológicas" (para usar o termo do articulista citado por Barroso) em oposição às qualidades do intelecto ${ }^{45}$. A conservadora parece trabalhar tendo como base conceitual o par antinômico alma/intelecto, a partir do qual deriva outro par, só que agora complementar: fiéis e fanáticos/jagunços e guerrilheiros.

Conforme se desenrola o ensaio, fica claro que, embora os objetos sejam as grandes revoltas camponesas - Canudos, Contestado e Juazeiro -, subjaz uma questão que parece nortear toda a linha de raciocínio: as relações do Estado com a massa popular têm de ser baseadas na violência, pois existe uma predisposição natural à desordem entre os últimos, predisposição cujas origens estão na preponderância da alma sobre o intelecto. Esta tendência predispõe o sertanejo não apenas ao fanatismo, mas ao crime. Fala a investigadora:

\footnotetext{
No sertão há sempre uma herança de crime, que só se responde com outro crime, famílias que se degladiam, que cultivam o ódio através de gerações.

A desconfiança, a suscetibilidade do sertanejo será também um passo para o crime. À desafronta, ao insulto, responde matando ${ }^{46}$.
}

Com este raciocínio, a senhora Levy inicia uma digressão cujo objetivo é explicar a formação de bandos de cangaceiros. Ela não parece, entretanto, fazer grande distinção entre cangaceiros e fanáticos, a não ser talvez pelo fato de que uns já mataram alguém e outros ainda não. São ambos seres comandados pela violência e pelas paixões. Não podemos deixar de ver, neste ponto, uma analogia com o conceito de Sturm und Drang - violência e impetuosidade, ao pé da letra -, presente em toda a produção artística romântica, da poesia à pintura, e que é a principal arma na luta contra a cultura da razão, em que se engajavam os românticos. Não estamos afirmando que a senhora Levy, ou qualquer um dos seus colegas conservadores, fosse romântica por ideologia. Mas pode-se observar que suas fontes de informação, no que diz respeito à análise da
44. LEVY, F. Crentes e bandidos. Anais do Museu Histórico Nacional, v. 8 , p. 31,1947 .

45. Id., p. 32.

46. Id., p. 53. 
47. BARroso, G. Esquematização da história militar do Brasil.Anais do Museu Histórico Nacional, v.3, p. 412, 1942.

48. Id., p. 426

49. Sobre o assunto ver ABREU, Regina. O paradigma evolucionista e $O$ Museu Histórico Nacional. In: CADERNOS de Pesquisa. Rio de Janeiro: Museu Histórico Nacional, 1989. n. 1 categoria "povo", são os folcloristas, estes sim parcialmente inspirados pelo romantismo. Isto a faz absorver parcialmente a linha que considera o povo como entidade movida pelas paixões.

Mas, segundo a autora, seu objetivo não é um estudo dos fanáticos religiosos nem do banditismo social nordestino, mas de historiar três grandes centros de revolta camponesa: Canudos, Contestado e Juazeiro. De fato, os três case studies desenvolvidos parecem ter o objetivo de relacionar três momentos em que a ordem é rompida e a reação do Estado a elas. Por sinal, parece ser esse o único caminho pelo qual as grandes massas entram no museu de história: quando aparecem como uma ameaça ao Estado e se tornam objeto de sua violência reguladora.,

É interessante observar que, em meio ao texto, apontam algumas fotografias de objetos usados durante os episódios que a autora tem em tela: um rifle, um facão, um tambor, uma medalha, um rosário, uma bandeira e um clarim. A autora não os estuda em detalhes. Em outros artigos de sua autoria, objetos são cuidadosamente descritos. Neste caso, são apenas ilustrações em meio ao arrazoado da conservadora. Mas são também le acreditamos que seja esta sua principal função) signos do triunfo do Estado: estão no museu de história como troféus de guerra. E, em meio aos troféus, a fotografia de uma "corneta do $4^{\circ}$ Batalhão de Policia da Bahia que tocou a carga final em Canudos, quando o arraial foi ocupado à baioneta", testemunho da vitória das forças da ordem sobre a ameaça de rompimento da ordem. Trata-se de um "documento" que traz, impresso em si mesmo, a chancela oficial; os outros a adquiriram quando deram entrada no museu como troféus. E é este seu papel, pois de outra maneira teriam ido parar, no máximo, em algum museu de folclore.

Gustavo Barroso, a história, a tradição e a memória

A posição da questão Canudos está muito bem definida. No volume 3 dos Anais encontramos um artigo de Gustavo Barroso no qual o então diretor do Museu Histórico propõe uma "esquematização da história militar do Brasil". Tratase de um conjunto de sugestões de temas para estudo. No item denominado por Barroso "História das guerras internas", desenrola-se um conjunto de episódios acontecidos no interior do território nacional. O item c, denominado "Expedições punitivas", relaciona dois tópicos: Palmares e Canudos ${ }^{47}$. Barroso escrevia, por certo, de improviso, mais ou menos como quem prepara uma aula, e não deve ter lembrado de diversos outros levantes que fariam por merecer "expedições punitivas". Mas é significativo que sejam, no texto, os dois únicos momentos que escapam à classificação de campanha militar. Segundo o autor, tratava-se de "movimentos de tropas", destinados a "destruir focos de fanatismo e desordem na vastidão dos sertões" 48 .

Barroso via a formação social brasileira como uma espécie de reino da desordem, tanto é que se refere ao País como "de origem e formação tumultuárias". E vê o Exército como uma "ordem permanente", capaz de garantir a continuidade da vida nacional ${ }^{49}$. Quer dizer, o Exército é uma espécie de vanguarda armada do Estado, que inclusive possibilita a implantação deste. Por sobre o tumulto prevalece, pois, a ordem. 
artigo de Barroso presta-se para abordarmos a segunda das possibilidades de cruzamento do tema "massas populares" com o objeto do museu - a participação do povo no Estado.

Em princípio, se seguirmos estritamente a linha de raciocínio que tenho desenvolvido, a resposta é curta e direta - não há participação. $\bigcirc$ Estado é o campo, por excelência, das elites dominantes; o campo do intelecto, como já foi dito. Se fôssemos relacionar esta dicotomia (alma/intelecto) com aquela que temos considerado básica (inclusão/exclusão), teríamos agora um par complementar: inclusão/intelecto. As instituições do Estado são formadas pelas elites, ou por seus agregados diretos (a pequena burguesia, por exemplo). Mas, em algumas delas, é preciso mais do que isso, é preciso alguma substância. É o caso do Exército, pois esta instituição é formada por generais, mas também por soldados. Estes últimos nada têm de membros da elite. A senhora Levy até reconhece isso:

\section{[...] muitos cangaceiros preferem se matar a serem presos e trucidados pelos policiais (na maioria recrutados nas prisões), que além de darem vazão a seus instintos perversos, silenciavam o adversário para que este não denunciasse os malefícios dos oficiais e dos chefões ${ }^{50}$.}

Um pouco mais adiante, descrevendo as forças legalistas reunidas em torno do governador Franco Rabelo, que se lançou contra os fanáticos entrincheirados, durante o levante de 1913, comandado por Floro Bartolomeu e inspirado pelo padre Cícero, afirma que "[aos] rabelistas, defensores do governador [...] incorporam-se civis e são recrutados sentenciados patriotas" ${ }^{\prime \prime} 1$.

A mesma massa indisciplinada, "tumultuária", que consubstancia as fileiras de fanáticos amotinados, alimenta as tropas do Estado, aquelas que impõem a ordem. Mas isto não torna menor a história militar brasileira. Como constata Gustavo Barroso:

\begin{abstract}
Em verdade, no nosso continente, nenhum povo conta, no acervo de seu passado, campanhas iguais às nossas [...] Nossa história militar possuí vultos e glórias fora do comum, e até repleta de grandes ensinamentos técnicos e políticos [...] Ilustra-se de belos exemplos. A tradição de episódios, praxes, indumentárias, instituições e organizações pode ser invocada constantemente como base irremovível e inspiração fecunda de novas construções exigidas pelo nosso tempo ${ }^{52}$.
\end{abstract}

Ao longo das trinta páginas seguintes, Barroso desfia um exército quase ideal. Um exército sem soldados. $\bigcirc$ jargão militar que ele tenta usar pode confundir um pouco: utiliza a palavra soldado, mas para referir-se aos generais: este termo, no contexto do uso, conota uma série de virtudes militares. Por exemplo:

Os grandes vultos militares concisamente biografados formarão uma respeitável e solene galeria de exemplos vivos de bravura, lealdade, competência, espírito de sacrifício, compreensão do dever e amor à Pátria. Heróis da guerra holandesa [... soldados coloniais como Rafael Pinto Bandeira, [...] soldados imperiais como [...] Osório [...] Sampaio [...] e Câmara; soldados da República como Floriano e Deodoro ${ }^{53}$.

As "concisas biografias" não chegariam nunca a contar as vidas do cabo Chico Diabo, que o acaso fez matar Solano Lopez, ou do anspeçada Marcelino Bispo, que assassinou o marechal Bittencourt durante a parada comemorativa da vitória sobre Canudos. Em graus diferentes, esses dois homens
50. LEVY, F. op. cit. Anais do Museu Histórico Nacional, v. 8, p. 37, 1947.

51. Id., p. 66. O grifo é da autora.

52. BARROSO, G. op. cit. Anais do Museu Histórico Nacional, v. 3, p. 401, 1942.

53. Id., p. 429 
54. Museu Histórico Nacional/Reserva Técnica. Inventário da Coleção de Armaria. [193?]. Ms. [atribuído a Gustavo Barroso.]. tiveram sua memória conservada no museu de história não por representarem o espírito de uma instituição do Estado, mas por estarem envolvidos em um evento singular. Como indivíduos, eles desapareceram, dando lugar aos próprios eventos, ou, no caso do Museu, aos objetos legados por tais eventos: a lança com que o cabo matou o ditador paraguaio, e a grade onde se enforcou lou, mais provavelmente, foi enforcado) o anspeçada Bispo.

Não é que não haja, no Museu, lugar para soldados rasos. No início dos anos 30, a coleção de armas reunida pela instituição montava a 1.229 itens. Em meio a estes, muitos não eram armas propriamente ditas: havia retratos de ministros da Guerra, escudos do $1^{\circ}$ e $2^{\circ}$ Reinados e instrumentos de banda marcial. Um levantamento no inventário da coleção ${ }^{54}$ nos apresenta alguns dados dignos de nota. Em primeiro lugar, dificilmente os itens são individualizados: os possuidores não são registrados, mas somente os doadores. Quando se observa a pesquisa feita pelo conservador que tratou a coleção, nota-se que muitas das armas, particularmente as espadas, são ligadas a alguma instituição. $\bigcirc$ objeto número 522 é dado como Sabre de oficial da Guarda Nacional; o de número 529, como Sabre da artilharia montada; o número 698, como Espada-baioneta do 1 o Batalhão de Caçadores. A quase totalidade dos objetos é individualizada dessa maneira. A pesquisa do objeto, quando há le são muitos os casos em que o item traz a reboque um curto dado informativo), remete-se geralmente a algum aspecto histórico, ou à origem de sua denominação. Um outro dado significativo é que quando o objeto é uma arma de fogo, a pesquisa geralmente remete-se a algum dado técnico ou referente à origem do item descrito. Parece que o autor do texło associava as espadas à mais pura tradição militar, enquanto as armas de fogo remetem-se à questão técnica, importante nos exércitos modernos, mas menos relacionada à tradição.

No conjunto, a reunião de objetos parece indicar que os homens sem histórias extraordinárias são, no museu, substituídos pelos objetos. Mas estes, por sua vez, não têm nenhuma obrigação imediata de os conotar, mas somente à instituição de que faziam parte. Ainda assim, chamou minha atenção a quantidade de espadas de oficial. Ora, os exércitos têm, em seus quadros, oficiais e soldados. No Museu Histórico, os últimos desapareceram, dando lugar à informações como, por exemplo, aquela adenda ao objeto número 587, dado como Sabre de infantaria. Brasil-Reino. Industrie Royal de Klingenthal. Coclaine Fréres. A informação que se segue procura historiar a evolução deste modelo de arma desde o período colonial. $O$ texto refere-se a infantaria de linha, granadeiros e fuzileiros, mas sem chegar a esclarecer que estes nomes referiam-se à massa de manobra do Exército, quer dizer os soldados. Eu até poderia dizer, talvez, que este dado está implícito. De fato, realmente está, e este parece ser o centro da questão. Soldado é um termo militar, mas também é uma qualidade, assim como oficial é uma qualidade. $\bigcirc$ oficial comanda, o soldado obedece. O oficial é geralmente recrutado, a partir do século XIX, nas camadas médias e altas da população; no Antigo Regime, procediam da pequena nobreza; o soldado vem das camadas mais baixas. Mas os exércitos não existem sem eles. $O$ museu de história não pode ignorá-los.

O jeito encontrado parece ter sido substitúílos pelos itens que os caracterizavam na instituição. Uma operação de metáfora, quer dizer, que institui uma analogia, substituindo um termo por outro. Os oficiais continuam oficiais porque são a expressão do Estado - de certa maneira, o museu é deles, tanto 
quanto é dos imperadores, dos ministros e da nobreza. Mas os soldados procedem das massas populares, objetos da história. Estariam no lugar certo? Barroso, o grande especialista, parece ter dúvidas, tanto é que, a certa altura de seu artigo sobre história militar, diz:

\begin{abstract}
A tradição e a glória são as duas colunas que sustentam um Exército. Uma tradição ele traz consigo mesmo expressa na sua organização, na sua indumentária, na sua doutrina, no seu espírito. Outra o cerca na memória dos povos. Essa é o folclore militar; episódios que não estão na história, recontos individuais, reminiscências de famílias, notas particulares, lendas, canções, cantigas, trovas, anedotário.

Já tentei uma vez reunir o material folclórico sobre a guerra do Paraguai e vi que era rico, mas que exigia um tempo que eu não dispunha. A minha tentativa restringiu-se a meia dúzia de artigos no $\bigcirc$ Jorna ${ }^{55}$.
\end{abstract}

autor parece interessado em ressaltar, nesse pequeno trecho, alguns pontos. $\bigcirc$ primeiro é seu desinteresse pelo folclore. Tanto quanto no artigo sobre - Museu ergológico, frisa reconhecer a importância e a riqueza do tema, mas afirma não ter tempo para ele, talvez por ser campo de folcloristas e etnógrafos, não de historiadores. $\bigcirc$ segundo é a dicotomização entre tradição - os aspectos propriamente históricos; e glória - aspectos que ele liga à "memória dos povos". No entender de Barroso, são feitos e fatos fora da história, o que significa, segundo a lógica da historiografia que o informava, não documentados, isto é, restritos à memória dos povos. Isso significa sem possibilidade de serem legalizados e fora, por conseguinte, do museu de história.

A triste história de Raimundo Carmo Filho e sua relíquia em que ninguém acreditava

raciocínio de Barroso, sem dúvida ideólogo do Museu Histórico, avança até construir uma lógica que, baseada na investigação de indícios, inaugura uma disciplina que chamaremos indiciária, seguindo os passos de Ginzburg, quando este diz que

\footnotetext{
[...] o grupo de disciplinas que chamamos de indiciárias (incluída a medicina) não entra absolutamente nos critérios de cientificidade deduzíveis do paradigma galileano. Tratase, de fato, de disciplinas eminentemente qualitativas, que têm por objeto casos, situações e documentos individuais, enquanto individuais, e justamente por isso alcançam resultados que têm uma margem ineliminável de casualidade: basta pensar no peso das conjecturas [...] na medicina ou na filologia. [...] A ciência galileana tinha uma natureza totalmente diversa, que poderia adotar o lema escolástico individuum est ineffabile, do que é individual não se pode falar ${ }^{56}$.
}

Segundo esse autor, "a história manteve-se como uma ciência social [...] irremediavelmente ligada ao concreto. [...] sua estratégia cognosciva, assim como seus códigos expressivos permanecem intrinsecamente individualizantes" 57 .

No início do artigo, Ginzburg fala de um método de trabalho, o "método morelliano", e o artigo segue observando como tal método é a expressão de certas características das disciplinas que ele denomina indiciárias, que se baseiam antes de tudo na observação sensível, quer dizer, na busca de
55. BARROSO, G. Esquematização da história militar do Brasil.Anais do Museu Histórico Nacio$n a l$, v. 3, p. 430, 1942 . O primeiro grifo é nosso.

56. GINZBURG, C. Raízes [...] op. cit., p. 156.

57. Id., p. 157. 
58. HORTA, M.L. P.op.cit Cadernos Museológicos. op. cit., p. 85

59. Id., p. 87 indícios. É exatamente o que Barroso e seus conservadores faziam, só que eles, tanto quanto os historiadores do século XIX, passavam o tempo todo procurando encontrar o estatuto científico, ou seja, rigoroso, da disciplina que dominavam. Sabemos que tal estatuto reside na crítica, precisamente na crítica textual que elimina o dado sensível.

No caso da disciplina que Barroso e seus colegas praticavam (na falta de nome melhor, chamemos de história material), a essência do trabalho era, exatamente, separar objetos históricos de objetos não históricos. Reconhecer tais objetos implicava colocar em questão os dados sensíveis por meio do rigor "científico" da pesquisa, isto é, do recurso à legalização. Os objetos históricos trazem, quase intrínseca, essa chancela, pela qualidade. Basta recordarmos a conservadora Carvalho, falando do sabre de honra que se auto-autenticava. Quando fez essa afirmação, a senhora Carvalho queria dizer que um objeto de tamanha qualidade não poderia vir de qualquer lugar. Ainda assim, deu-se ao trabalho de investigá-lo cuidadosamente, pois não poderia confiar exclusivamente em seus sentidos e sentimentos.

O método dos conservadores devia resultar num discurso adequado aos objetivos da instituição onde trabalhavam. Parece-nos que a questão é bem definida por Maria de Lourdes Horta, quando propõe que a

[...] chance de experimentar uma comunicação de primeiro nível - a relação direta com os objetos ou bens culturais - é uma das características específicas dos museus como um sistema de comunicação. A relação sujeito/objeto é uma relação direta do receptor com a mensagem. Não é, entretanto, uma relação direta emissor/receptor, não havendo portanto oportunidade para um feed-back que possibilite o ajuste da comunicação, e sua clarificação ${ }^{58}$.

Barroso e os outros conservadores lidavam com esse problema: não podiam deixar dúvidas em torno da mensagem, mas não estavam lá para esclarecer dúvidas ou pontos cegos. Na ausência do emissor, a relação comunicativa tinha de ser regulada de forma a evitar que qualquer distorção de conteúdo atingisse o receptor. Neste sentido, a autora a que recorremos estabelece que:

[...] como se trata de um processo de tradução, o meio museológico possibilita algumas distorções da mensagem original, principalmente quando o código usado não é claro ou conhecido do público. A distorção pode também ocorrer através da manipulação, consciente ou não, dos meios de comunicação, o que pode afetar basicamente o processo de decodificação 59 .

No caso, a distorção parece ser o método através do qual regula-se a relação comunicativa, de maneira que não restem dúvidas quanto ao conteúdo. Os conservadores deveriam, antes de mais nada, conhecer muito bem os limites que, na dicotomia inclusão/exclusão, separavam estes dois termos. Tal conhecimento era dado pela formação do especialista e pela prática, resultando em separar cuidadosamente o que podia entrar no museu de história daquilo que não podia. $O$ resultado era uma enorme distorção, que se manifestava na separação entre Estado e sociedade, que se tornavam objetos de museus diferentes.

Aqui chegamos à demonstração mais eloqüente daquilo que chamamos, um pouco atrás, de "cruzamento". No artigo sobre história militar, Barroso afirma que o Exército traz, impressa nele mesmo, a tradição. Mas, em última análise, a 
própria procedência dos objetos militares (doados por indivíduos relevantes, como os descendentes do barão da Vitória, ou originários do próprio Exércitol os chancela. $O$ diretor do Museu Histórico e seus subordinados estavam construindo um texto, suporte de um discurso, adequados ambos a uma instituição com as características do Museu Histórico Nacional.

Em 1930, Barroso fez publicar uma coletânea chamada $\bigcirc$ Brasil em face do Prata. Tratava-se de um livro com dezenas de artigos em torno de questões relativas às guerras brasileiras do século XIX, e um dos artigos intitula-se "A faca de Solano Lopez". Começa assim:

\begin{abstract}
À redação dum dos jornais de Fortaleza [...] compareceu há tempos o sr. Raimundo do Carmo Filho, cego e pai de dezesseis filhos. Chamando atenção para seu triste estado de pobreza, esse velho cearense trazia consigo uma preciosa relíquia histórica, da qual se queria desfazer para atender a necessidades pecuniárias. E exibiu aos olhos dos redatores uma faca de aço, de fabricação espanhola, com o cabo de prata lavrada, a lâmina incrustada de ouro de má liga. [...] Assegurava mais que aquela faca pertencera ao ditador do Paraguai, Francisco Solano Lopez ${ }^{60}$.
\end{abstract}

Nas linhas seguintes, o autor resume a versão de como a faca teria chegado às mãos do pobre cearense. A certa altura, afirma peremptoriamente: "Nela nenhum característico autoriza a afirmar que tenha pertencido ao ditador paraguaio. E os documentos relativos à morte do mesmo não se referem a uma faca" 61 .

As páginas seguintes são gastas com uma descrição dos objetos de Lopez existentes no Museu Histórico Nacional. Sobre a espada do "ditador paraguaio", Barroso afirma que "está documentada por ela própria", mas também "pelos ofícios de remessa" - quer dizer, documentos do exército -, e por fotografias onde Lopez a está portando. Sobre um relógio de sol, simplesmente "tem as armas paraguaias e inscrições que o autenticam". Em seguida: "O relógio de sol foi trazido pelo velho marechal Mendes de Moraes".

Ora, um relógio pode perfeitamente ser falsificado. As armas do Paraguai e o testemunho do "velho marechal", tão-somente, não autenticam coisa alguma: as armas poderiam ter sido apostas ao objeto e o "velho marechal" podia estar senil. Documentos positivos, ao que parece, não existiam. Se há algum inventário dos objetos saqueados ao cadáver de Solano Lopez, Barroso não fala. Ao contrário, prefere referir-se aos depoimentos de "homens de letras" e de "ilustres generais" como chancelas de peritagem e autenticação. Sobre a faca, diz simplesmente: "[...] dela nunca se ouviu falar e quer me parecer que se não apresenta com documentação suficiente ${ }^{62}$

As dezenas de trabalhos publicados por Barroso tendo objetos materiais como base revelam um intelectual bastante rigoroso com seu trabalho. Não que os resultados sejam sempre excepcionalmente bons. Mas o fato é que se mantinha estritamente dentro dos limites estabelecidos pela dicotomia inclusão/ exclusão, e pode-se acrescentar que tais limites não foram estabelecidos por ele, que apenas os aperfeiçou. Assim, o pobre senhor Raimundo do Carmo, cego e pai de dezesseis filhos, não poderia testemunhar sobre uma relíquia histórica, pois não tinha o Estado por trás de si, a autenticá-lo, mais do que à sua singela relíquia.

Numa sociedade rigidamente hierarquizada, cada coisa tem seu lugar. $\bigcirc$ lugar dos inúmeros e inominados Raimundos não é o museu de história. Eles não têm chancela. Seu território é a "memória dos povos". Tanto quanto o povo
60. BARROSO, G.A faca de 
63. GINZBURG, C. Raízes [...] In: MITOS emblemas e sinais. Op. cit., p. 175.

64. BARROSO, G. A faca [...] op. cit., p. 292. que the dá origem, a memória é "tumultuária", e seus testemunhos, inconfiáveis. Com os Raimundos, o Estado pode apenas ser condescendente. Tal condescendência aparece quando Barroso diz, sem muita confiança [...] "Não é impossível que a faca seja verdadeira."

Não é impossível, mas as "provas" estão contra.

[...] Purkyne, que quando jovem estudara filosofia em Praga, reencontrava os temas mais profundos do pensamento de Leibnitz. $\bigcirc$ indivíduo, "ens omnimodo determinatum" [ente totalmente determinado], possui uma singularidade verificável até em suas características infinitesimais. Nem o acaso nem os influxos externos bastam para explicála. É necessário supor a existência de uma norma ou typus interno, que mantém a diversidade dos organismos dentro dos limites de cada espécie: o conhecimento dessa "norma" (afirmava profeticamente Purkyne) "descerraria o conhecimento oculto da natureza individual". O erro da fisiognomia foi enfrentar a diversidade dos indivíduos à luz de opiniões preconcebidas e conjecturas apressadas [...] Purkyne concentrou a sua atenção num dado muito menos aparente - e nas linhas impressas nas pontas dos dedos encontrava a senha oculta da individualidade ${ }^{63}$.

Barroso e os conservadores, tripulantes da nau de uma disciplina que se pretende científica mas que lida com um conhecimento "indireto, indiciário e conjetural", ligado ao concreto, não aplicam a esmo os parâmetros que determinarão o lugar de cada coisa e colocarão cada coisa em seu lugar. Examinam indícios e procuram indícios. No caso de Raimundo, os indícios eram evidentes demais: o próprio chamava atenção para seu "triste estado de pobreza". Era esta a "senha oculta da individualidade" que o situava.

Excluído por todos os lados, Raimundo não chegou a ter misericórdia de Barroso. No museu de história, de jeito nenhum. Mas, se o diretor do Museu Histórico colocava a categoria "tradição" como um dos pilares sobre o qual se constrói a nação, então o pobre cearense, a depender de sua faca, nem lugar no Brasil teria, como talvez não tivessem as grandes massas de que fazia parte, por seus atributos perceptíveis.

Exagero? Bem, que fale o próprio Barroso.

Andaram os positivistas e "positivóides" do Rio de Janeiro assanhados para restituir troféus paraguaios ao presidente Guggiari, quando este ilustre estadista nos visitou. Cortei-lhes as vazas e não the entregaram nada. Como ficha de consolação, poderiam agora adquirir a tal faca, que está exposta à venda em Fortaleza, e remetê-la para Assunção. Dou minha palavra de honra que não me oporei de maneira alguma $[\ldots]^{64}$.

\section{REFERÊNCIAS}

ABREU, Regina. A fabricação do imortal:A coleção Miguel Calmon no Museu Histórico Nacional. Rio de Janeiro: Rocco/Livros Lapa, 1997.

ABREU, Regina. O paradigma evolucionista e o Museu Histórico Nacional.In:CADERNOS de Pesquisa. Rio de Janeiro: Museu Histórico Nacional, 1989. n. 1

ALEXANDER, P. Museums in motion. Nashville (EUA):American Association for State and Local History, 1979. cap. 5. 
BARROSO, G. O Brazil em face do Prata. Rio de Janeiro: Imp. Nacional, 1930.

BARROSO, G. Esquematização da história militar do Brasil.Anais do Museu Histórico Nacional, v. 3, p. 412, 1942.

BARROSO, G. Esquematização da história militar do Brasil.Anais do Museu Histórico Nacional, v. 3, p. 430, 1942.

BARROSO, G.A heráldica dos vice-reis. Anais do Museu Histórico Nacional, v. 3, p. 5-6, 1942.

BARROSO, G. Museu ergológico brasileiro.Anais do Museu Histórico Nacional, v. 3, p. 433, 1942.

BRASIL. Museu Histórico Nacional. Catálogo geral. Rio de Janeiro: Imp. Nacional, 1924.

BUCCAILE, R.; PESEZ, J. -M. Cultura material. In:ROMANO, R. (Org.). Enciclopédia Einaudi. Lisboa: Imp. Nacional : Casa da Moeda, 1989. v. 17, p. 44.

CARVALHO, Nair de M. O Barão da Vitória no Museu Histórico.Anais do Museu Histórico Nacional, v. 3, p. $227,1942$.

DELOCHE, B.Museologia e instituições museológicas como agentes ativos da mudança: passado, presente e futuro. 2. ed. Rio de Janeiro:SPHAN/Pró-Memória, 1990.p. 54-58.(Cadernos museológicos, n. 2, dez. 1989).

DUMANS,A.A idéia da criação do Museu Histórico Nacional.Anais do Museu Histórico Nacional, v. 3, p. 388, 1942 .

GINZBURG, C. O queijo e os vermes. São Paulo: Cia das Letras, 1989. p. 29.

GINZBURG, C. Sinais - raízes de um paradigma indiciário. In: Mitos, emblemas, sinais: morfologia e história. São Paulo: Cia das Letras, 1990. p. 143-179.

HOBSBAWN, E. A era do capital.3. ed. Rio de Janeiro: Paz e Terra, 1982. p. 104.

HOOPER-GREENHILL, E. The National Portrait Gallery - a case-study in cultural reproduction. Londres: London Institute of Education, 1980. p. 27. Mimeo.

. The museum in a disciplinary society. In: PEARCE, S. (Ed.) Museum studies in material culture. London: Leicester University Press, 1989.

HORTA, M. L.P.O processo de comunicação em museus. 2.ed. Rio de Janeiro:SPHAN/Pró-Memória, 1990. p. 65-90. (Cadernos Museológicos, n. 1, set. 1989).

LACORTE,V.Escola de civismo. In: ORNELLAS, P. da V. Relíquias da pátria brasileira. Rio de Janeiro: [s.n.], 1944. p. 23.

LEVY, F. Crentes e bandidos. Anais do Museu Histórico Nacional, v. 8, p. 31, 1947.

PEARCE, S. Museum studies in material culture: introduction. In: PEARCE, S. (Ed.). Museum studies in material culture. London: Leicester University Press, 1989. p. 1. 
PORTER, R.;TEICH,M.(Ed.).Romanticism in national context. Cambridge: Cambridge Univ. Press, 1988. p. 1.

WILLIAMNS, Daryle. Sobre patronos, heróis e visitantes: O Museu Histórico Nacional, 1930-1960. Anais do Museu Histórico Nacional, v. 29, p. 141-183, 1997.

WINZ,A. P. História da Casa do Trem. Rio de Janeiro: Museu Histórico Nacional, 1962. cap. XIII.

Artigo reapresentado em 3/2003. Aprovado em 7/2003. 
Uniformes da Guarda Nacional; 183 1-1852. A indumentária na organização e funcionamento de uma associação armada

Adilson José de Almeida

objetivo desta pesquisa sobre uniformes da Guarda Nacional foi examinar a utilização de indumentária na organização e funcionamento de uma associação armada. Um passo inicial para estudarmos o vestuário como um vetor material da produção e reprodução social. Não se trata, portanto, do estudo de um artefato, mas de suas funções, pragmáticas, diacríticas e simbólicas, meios para análise de problemas mais amplos relativos à organização, desenvolvimento e mudança de sociedades.

PALAVRAS-CHAVE: Uniformes Militares. Vestuário. Guarda Nacional. Cultura Material.

Anais do Museu Paulista. São Paulo. N. Sér. v. 8/9. p.77-147 (2000-2001). Editado em 2003.

Uniforms of the National Guard; 1831-1852. The clothes in the organization and functionality of a military force

Adilson José de Almeida

The aim of this research about the National Guard uniforms was to examine the use of this apparel in the organization and functioning of a military force. An initial step in order to study the apparel as a material vector of the social production and reproduction. It is not, therefore, from the study of an artefact, but from its functions, pragmatic, diacritical and symbolic, means to analyse bigger problems regarding organization, development and change in the societies.

KEYWORDS: Military Uniforms.Apparel. National Guard. Material Culture.

Anais do Museu Paulista. São Paulo. N. Sér. v. 8/9. p.77-147 (2000-2001). Editado em 2003.

Cada coisa em seu lugar. Ensaio de interpretação do discurso de um museu de história

José Bittencourt

O Museu Histórico Nacional, situado no Rio de Janeiro, foi criado em 1922, como parte das comemorações do Centenário da Independência do Brasil. Ao longo dos seguintes 38 anos, foi dirigido por Gustavo Barroso. Este intelectual, figura bastante fípica da "república das letras" brasileira, imprimiu no MHN uma forte marca pessoal, cristalizada no discurso conservador expresso pelas exposições. Baseado nas formulações teóricas de Carlo Ginzburg, conforme apresentadas em um artigo intitulado "Sinais - raízes de um paradigma indiciário", bem como em diversos textos que abordam museus como discursos, o autor analisa a exposição do MHN nos anos 30, 40 e 50. Apoiando-se também na produção científica dos conservadores, publicada em livros e na revista institucional, os "Anais do Museu Histórico Nacional", procura ver o circuito como representação das posições ocupadas pelos "agentes ativos da história" - aristocracia, funcionários públicos civis e militares, dentre outras categorias - em relação a uma categoria não claramente definida, o "povo", que foi representada através da ausência.

PALAVRAS-CHAVE: Museus. Museologia. Cultura Material. História de Exposições. Museu Histórico Nacional (Rio de Janeiro). Anais do Museu Paulista. São Paulo. N. Sér. v. 8/9. p.151-174 (2000-2001). Editado em 2003.

Each thing in its place. Essay on the interpretation of a history museum's speech

José Bittencourt

The National History Museum (Museu Histórico Nacional), in Rio de Janeiro, was created in 1922, as part of the commemorations of Brazil's Independence Centennial party. Throughout the next 38 years, it has been run by Gustavo Barroso. This intellectual person, a typical character of the Brazilian " republic of the letters", left a personal mark in the MHN (the museum), crystallized in the conservative discourse expressed in the exhibitions. Based in Carlos Ginzburg's theoretical formulations, as presented in an article entitles "Signs - routes of an indicting paradigm", as well as in various essays about museums as discourse, the author analyses the exhibition in the MHN in the 30's, 40's and 50's. Getting an additional support in the scientific production of the conservatives, published in books and in the institutional magazine, the "Annals of the National History Museum ("Anais do Museu Histórico Nacional"), tries to see the exhibition circuit as a representation of the positions filled by the "active agents of History" - aristocracy, civil and military public workers, among other categories - in relation to a category which is not clearly defined, the "people", which was represented by its absence. 